\title{
Vital Need for Sex Education in Indian Youth and Adolescents
}

\author{
Rajni Sharma $^{1}$
}

Received: 4 February 2020 / Accepted: 5 February 2020 / Published online: 11 February 2020

(C) Dr. K C Chaudhuri Foundation 2020

Young adults (aged 19-24 y) and adolescents (10-19 y) constitute $31 \%$ of the Indian population and have unique health needs of which sexual health is very important though often neglected area [1]. This age group is especially vulnerable to experimentation and risky behavior including premarital sex and sexual abuse, exposing them to sexually transmitted diseases, unwanted pregnancy/abortion and psychological problems [2]. More than one-third of new cases of HIV/AIDS in India occur in the age group of 15-24 y [1]. According to NFHS- 4 data, only $21 \%$ and $32 \%$ adult women and men, respectively, had comprehensive knowledge of HIV/AIDS and only $50 \%$ women knew about safe sex practices [3]. Furthermore, in the absence of authentic sources, adolescents and young adults frequently get wrong information from peers or mass media. Hence, sex education, also known as family life education (FLE), is paramount to impart correct knowledge as well as shape the right attitudes, beliefs and values [4].

However, delivery of sex education to this vulnerable group has been a challenge. The topic of sex is considered taboo and there is reluctance on part of the parents to discuss these issues at home. There are very few dedicated adolescent health clinics and health professionals may be ill-equipped to address their sex education needs. The National AIDS Control Organization and Ministry of Human Resource Development had designed the adolescent FLE for schools but it was mired in controversy and there was resistance from various Indian states in incorporating it in the curriculum [5].

In this issue, researchers from the National Research Institute, Pune, Brahme et al., report sex behavior, attitudes and education needs of college students [6]. Some important findings of their study include the perceived importance of parents in imparting sex education, need for early initiation

Rajni Sharma

drrajnisharma@yahoo.com

1 Division of Pediatric Endocrinology, Department of Pediatrics, All India Institute of Medical Sciences, New Delhi, India of FLE beginning at $10 \mathrm{y}$ of age in schools, and a demand for age-appropriate mobile apps in the era of smartphones. More such studies are needed from other parts of India to understand the sexual knowledge, attitude and beliefs of adolescents and young adults. These studies will help in designing education material, training programmes for teachers/health professionals/parents and mobile apps to address the sex education needs of Indian youth in a socio-culturally acceptable, scientific and effective manner.

\section{Compliance with Ethical Standards}

Conflict of Interest None.

\section{References}

1. Young People and HIV/AIDS - World Health Organization [PDF]. Available at: apps.searo.who.int $>$ PDS DOCS. Accessed $29^{\text {th }}$ January 2020.

2. Ramadugu S, Ryali V, Srivastava K, Bhat PS, Prakash J. Understanding sexuality among Indian urban school adolescents. Ind Psychiatry J. 2011;20:49-55.

3. National Family Health Survey-4 Document [PDF]. Available at: http://rchiips.org/NFHS/pdf/NFHS4/India.pdf. Accessed $29^{\text {th }}$ Jan 2020.

4. Ismail S, Shajahan A, Sathyanarayana Rao TS, Wylie K. Adolescent sex education in India: current perspectives. Indian J Psychiatry. 2015;57:333-7.

5. Tripathi N, Sekher TV. Youth in India ready for sex education? Emerging evidence from national surveys. PLoS One. 2013;8: e71584.

6. Brahme R, Mamulwar M, Rahane G, et al. A qualitative exploration to understand the sexual behavior and needs of young adults: a study among college students of Pune. India Indian J Pediatr. 2020. https:// doi.org/10.1007/s12098-019-03160-7.

Publisher's Note Springer Nature remains neutral with regard to jurisdictional claims in published maps and institutional affiliations. 